\title{
Måling af behandlingsudbyttet af fængselsindsatser - en diskussion af GPPM ${ }^{1}$
}

Af Nichlas Permin Berger, cand.soc. Ph.D., forsker, VIVE-Det

Nationale Forsknings- og Analysecenter for Velfaerd

Jacob Ladenburg, cand.silv., ph.d., seniorforsker, Rockwool

Fondens Forskningsenhed

Ulf Hjelmar, mag.art., ph.d., programleder, VIVE-Det Nationale

Forsknings- og Analysecenter for Velfaerd

\begin{abstract}
In 2016, the Danish Prison and Probation Service introduced the Canadian tool GPPM (Generic Program Performance Measure for Correctional Programs) as part of MOVE, a cognitive-behavioural program for prisoners recently developed in Denmark. The tool measures the performance and progress of participants in correctional programs and allows the rating of offenders' skill development, motivation levels, attitude changes and program participation. Furthermore, GPPM output is used to give structured personal feedback to the individual participants on their performance during and after the completion of the program in order to support prisoners' developmental improvement. Using Danish correctional program data (LS/RNR) and GPPM results from 50 prisoners, we examine the different dimensions of the GPPM tool and discuss the possibilities of improving its applicability. First, we identify three separate dimensions of participant performance and argue that they provide a more detailed and accurate measure than the two dimensions identified by the original tool. Second, we find that the use of LS/RNR data in combination with GPPM data increases the likelihood of correctly identifying which prisoners will benefit from specific rehabilitation programmes thereby contributing to overall program effectiveness. Third, we note that an overemphasis on high-risk prisoners may distract from the fact that program participation for lowrisk prisoners can prevent an increase in their risk levels over time.
\end{abstract}

\section{Baggrund}

Der er de senere år produceret omfattende viden om vigtigheden af, at indsatte gennemfører evidensbaserede rehabiliteringsprogrammer, som kan reducere recidiv og derved beskytte offentlighedens sikkerhed (Wilson \& Davis 2006; Nagin, 
Cullen \& Jonson 2009). Samtidig er der ganske lidt evidens for, at fængsler rent faktisk reducerer recidiv, men nogen grad af evidens for, at fængsler skaber kriminogene effekter (Cullen et al. 2011). Dette gør det relevant at se på, om man kan forandre indsattes viden, holdninger, normer og værdier gennem deltagelse $\mathrm{i}$ målrettede rehabiliteringsprogrammer og derved give et positivt bidrag til de ellers overvejende negative effekter af fængselsafsoning.

Der findes generelt få validerede og standardiserede redskaber til at måle effektiviteten af fængselsprogrammer. Sådanne redskaber er velegnede til at undersøge og identificere, hvordan forskellige dele af et fængselsprogram påvirker forskellige typer af deltagere. Generic Program Performance Measure for Correctional Programs (GPPM) er et sådan redskab og dette vil vi i artiklen stille skarpt på.

\section{Udvikling og anvendelse af GPPM}

GPPM er et anerkendt og empirisk valideret redskab, som er udviklet til at undersøge effektivitet på tværs af forskellige fængsels-programmer. Gennem anvendelse af GPPM kan man måle på en række forskellige dimensioner af deltagernes svar og herved bidrage til analyser af deltagernes udbytte af deltagelse i et givent fængsels-program.

GPPM blev første gang udviklet og anvendt inden for psykiatrien i 1968 (Kireshuk \& Sherman 1968; Kireshuk et al. 1994). GPPM er siden blevet videreudviklet særligt i den canadiske kriminalforsorg, ${ }^{2}$ hvor den i dag benyttes i vidt omfang. Som standardiseret redskab, giver GPPM frontmedarbejdere i fængsler mulighed for at bedømme, hvordan deltagelsen i et program virker i forhold til centrale mål for indsattes udvikling.

\subsection{Den teoretiske model for GPPM}

GPPM fokuserer på nogle særlige elementer i fængselsprogrammerne: Tilegnelse af viden om programmets indhold, motivation, holdningsændring og færdighedsudvikling samt selvforståelse for individuelle risikofaktorer for kriminalitet (Usher \& Stewart 2011). Alle disse elementer indgår i redskabet som målepunkter, som samlet set udgør de centrale indikatorer for et fængselsprograms effektivitet. Et argument for at benytte GPPM er, at redskabet ikke alene forholder sig til indsattes selvrapporterede motivation for forandring, men også indeholder et bredere fokus på deltageres udvikling i løbet af et program. I GPPM-redskabet indgår sytten spørgsmål, hvoraf tolv spørgsmål handler om forhold, der er gældende både før- og efter-deltagelsen i et fængselsprogram, og derved giver mulighed for at bedømme udviklingen i GPPM som funktion af programdeltagelsen (Stewart et al. 2015). ${ }^{3}$ 
I den originale, teoretiske opdeling GPPM findes tre validerede dimensioner: 1) Modtagelighed (spørgsmål 6-8+17), 2) Udførelse (spørgsmål 9-16) og 3) Indsats (spørgsmål 1-5) (Stewart et al. 2015). Tabel 1 (se afsnit 3) giver en oversigt over disse spørgsmål. I dimensionen Modtagelighed vurderes motivation, evne til at lære samt relationelle faktorer. Denne dimension handler om prosociale holdninger og værdier, graden af deltagerens selvregulerings- og sociale færdigheder samt motivationsforhold. I dimensionen Udførelse vurderes færdigheder, holdninger og relevant viden i forhold til programmets mål. Disse vurderinger er baseret på observationer af deltagelsen samt instruktørens første møder med deltagerne og handler om relationen til instruktøren og samarbejdet om fastsættelsen af mål og opnåelsen af dem. I dimensionen Indsats vurderes villighed til at lære og træne indholdet i programmet. En score for hver dimension udregnes ved at finde gennemsnittet hver dimension. En overordnet samlet score opnås ved at summere og udregne gennemsnit af efter-vurderingerne for de to dimensioner Udførelse og Indsats. Vurderinger angives på en 5-pointskala fra -2 til +2 .

\subsection{Introduktion af GPPM i Danmark}

GPPM blev for første gang anvendt i dansk kontekst i forbindelse med pilotprojektet MOVE, som blev afprøvet i Horserød Fængsel i 2016 og evalueret undervejs (Berger et al. 2017). Der blev i denne evaluering fundet en markant variation hen over deltagernes alder og risiko- og behovsvurderingsprofiler (fra LS/RNRscoren $^{4}$ ). Evalueringen peger på, at unge mellem 19 og 30 år med en middel LS/RNR-score har signifikant større udbytte af MOVE-programmet sammenlignet med unge med en høj/|meget høj LS/RNR-score og sammenlignet med de ældre deltagere (38-52 år) med middel og høj/meget høj LS/RNR-score. Evalueringen konkluderer, at der både er et potentiale for at løfte de unge med en høj/meget høj LS/RNR-score samt de ældre deltagere.

Resultaterne fra undersøgelsen bygger på beregning af den gennemsnitlige ændring i GPPM-scoren hen over de tolv spørgsmål både før og efter deltagelsen (se også databeskrivelsen i afsnit 4). Resultaterne giver derfor ikke indblik i, hvorfor unge med en middel LS/RNR-score mere præcist har det største forbedringspotentiale, og hvordan dette kan indarbejdes i et fængselsprogram.

\section{Den analytiske strategi}

I denne artikel vil vi diskutere mulig forbedring af GPPM, så redskabet mere præcist kan bidrage til analyser af indsattes udbytte af deltagelse i fængselsprogrammer. Dette gør vi ved at undersøge, hvorvidt de i Berger et al. (2017)'s afrapporterede resultater varierer hen over de 12 spørgsmål (spørgsmål 6-17) og se 
nærmere på de observerede forskelle i alder og i LS/RNR-relationer. Vi tester for variation ved at tage udgangspunkt $i$ den oprindelige teoretisk baserede inddeling af de tolv GPPM spørgsmål i de to dimensioner: Modtagelighed (Responsitivity, spørgsmål 6-8 og 17) og Udførelse (Performance, spørgsmål 9-16) (Usher and Stewart 2011) og i de tre underliggende dimensioner, som fremkom i analysen i Berger et al. (2017) af de samme spørgsmål.

Hvis der er variation i alder og LS/RNR-relationer i forhold til det målte udbytte af MOVE-programvirksomhed, så vil det være yderst interessant fra både et teoretisk synspunkt og et praktisk synspunkt. Teoretisk giver det mulighed for at udvikle GPPM redskabet, så dimensionerne der indgår i modellen mere præcist afspejler adfærds- og holdningsmønstre hos deltagerne. Ud fra et praktisk synspunkt giver det mulighed for mere præcist at kunne tilrettelægge fremtidige programindsatser i forhold til specifikke målgrupper og dermed øge udbyttet af programmerne.

I det følgende beskrives datagrundlaget for artiklen, herunder opdelingen af GPPM-scoren i forskellige dimensioner. Derefter fremlægges analysens resultater samt diskussion og konklusion.

\section{Datagrundlag og datatilgang}

Analysen af variationen i relationen mellem alder, LS/RNR-score og ændringen i GPPM-scoren er baseret på data indsamlet i forbindelse med pilotprojektet MOVE, som blev afprøvet i Horserød Fængsel i 2016 (Berger m.fl. 2017). Datagrundlaget for analysen i denne artikel er dels før-efter GPPM scorer for hver deltager i MOVE-pilotprojektet i Horserød Fængsel og dels LS/RNR-data.

\subsection{MOVE}

MOVE er et 8-ugers intensivt programforløb med to ugentlige sessioner af hver $2 \frac{1}{2}$ timers varighed. Programforløbet er udviklet til at motivere og styrke indsatte gennem afsoningsperioden og forberede løsladelsen. MOVE har til formål er at øge klientens opmærksomhed på sammenhængen mellem tanker, adfærd og konsekvenser, herunder skabe bedre forståelse for og bevidsthed om egne holdninger, værdier og om sociale relationers betydning for klientens situation. Desuden trænes de indsattes bevidsthed om fordele og ulemper ved kriminalitet, kommunikations- og problemhåndteringsfærdigheder samt evne til selvregulering.

MOVE er det første program i Kriminalforsorgen i Danmark, som er grundlagt på principperne fra den canadiske risikovurderingsmodel, RNR. RNR-modellen er udviklet af de canadiske forskere Don Andrews og James Bonta og tager udgangspunkt i den enkelte indsattes behov med henblik på at kunne tilrette- 
lægge en rehabiliterende indsats (Andrews \& Bonta 1994). Modellen opererer med principperne for de mest effektive rehabiliterende indsatser (Andrews 1995; 2001), a) kriminelles risiko (risk), b) den kriminelles behov (need) og c) den kriminelles modtagelighed over for en indsats (responsivity). Derudover indgår også et fjerde centralt princip, nemlig professionelt skøn, som er nødvendigt i forhold til implementeringen af modellens principper (Andrews, Bonta \& Hoge 1990). Der ligger omfattende kriminologisk forskning til grund for at udpege netop disse faktorer, som værende centrale for forebyggelse af kriminel adfærd (Andrews, Bonta, \& Wormith 2008; 2010).

\section{2. $L S / R N R$}

Det specifikke RNR-redskab, som kriminalforsorgen i Danmark har indført hedder LS/RNR 5 (Andrews, Bonta \& Wormith 2008; 2011). LS/RNR er et risiko- og behovsvurderingsredskab, der er baseret på de ovenfor beskrevne principper og er løbet de seneste 4-5 år introduceret i alle danske fængsler og i KiF (Kriminalforsorgen i Frihed) (Berger \& Hjelmar 2017; Clausen 2017).

Redskabet er udformet som et syv-siders semistruktureret spørgeskema og udfyldes ofte af en sags-behandler i fængslet. Skemaet giver mulighed for at vurdere den enkeltes risikofaktor for fremtidig kriminalitet gennem tildeling af en samlet risikoscore på mellem $0 \mathrm{og} 43$. Scoren er inddelt i risiko-grupper fra 0-4 (meget lav), 5-10 (lav), 11-19 (mellem), 20-29 (høj) til 30-43 (meget høj).

\subsection{MOVE-pilotprojektet $i$ Horserød Fcengsel}

Kriteriet for deltagelse i MOVE er at man har en mellem, høj eller meget høj risikoscore. I pilotprojektet deltog 50 indsatte, hvoraf 15 deltagere faldt fra undervejs. Halvdelen af frafaldene skyldtes fravær, hvor instruktørerne måtte tage deltagerne ud af programmet, fordi man ikke måtte fortsætte, hvis man var fraværende tre eller flere gange. De tre øvrige årsager til frafald, som instruktørerne angav, var 'manglende motivation', 'disciplinære flytninger til lukket afdeling' samt 'opstart af andre initiativer/ overflytninger'. ${ }^{6}$

I MOVE-programmet er de forskellige GPPM scores baseret på instruktørernes observationer af deltagernes karakteristika og adfærd. Instruktørerne havde modtaget forudgående undervisning i skemaet og havde derudover en konkrete række hjælpespørgsmål og eksempler, som var blevet anbefalet at benytte i dialogen med deltagerne. Generelt kan man sige, at sådanne vurderinger, som beror på instruktørers individuelle fortolkninger af deltagerne og af spørgsmålene giver rum for variation mellem de enkelte instruktører. For at undgå for meget uensartethed havde instruktørerne selv udviklet en praksis, hvor de vurderede den sam- 
me indsatte uafhængigt af hinanden. Når GPPM var fastlagt, blev GPPM efterfølgende benyttet til at give de indsatte feedback på deres deltagelse og deres præstationer.

\subsection{De teoretisk orienterede dimensioner fra den oprindelige GPPM-model}

Usher og Stewart (2011) argumenterer teoretisk for, at man bør skelne mellem deltagernes modtagelighed (responsivity) og udførelse (performance), og at de GPPM-spørgsmålene bør afspejle disse to dimensioner. Deltagernes modtagelighed (responsivitet) har at gøre med forhold, som må antages at styrke deltagerens evne til at lære fra det aktuelle program. Det er for eksempel at have en stærk og god relation til instruktøren, at der er enighed om målet (med programmet), at deltageren i udgangspunktet er godt motiveret for deltagelse, og at deltageren kan tilegne sig og forstå indholdet af materialet fra programmet. Udførelse af programmet (performance) handler om kompetencer, værdier og relevant viden i forhold til de mål, som programmet fastsætter.

I tabel 1 ses opdelingen af de 12 GPPM-spørgsmål, som stilles både før og efter gennemførelsen af fængselsprogrammet. Det skal bemærkes, at spørgsmålene følger nummeringen fra det oprindelige og bagvedliggende spørgeskema (1-17). Spørgsmålene er opgjort i forhold til de to oprindelige dimensioner fra Usher \& Stewart (2011) og de tre dimensioner, som vi identificerede i Berger et al. (2017):

\section{Tabel 1:Opdeling af GPPM-spørgsmål på baggrund af Usher \& Stewart (2011) og Berger et al. (2017)}

\begin{tabular}{|l|c|c|c|c|c|}
\hline & \multicolumn{2}{|c|}{$\begin{array}{c}\text { Teoretisk funderede } \\
\text { dimensioner fra Usher } \\
\text { \& Stewart (2011) }\end{array}$} & \multicolumn{2}{|c|}{$\begin{array}{l}\text { Nye dimensioner udviklet fra dan- } \\
\text { ske data fra Berger et al. (2017) }\end{array}$} \\
\hline & $\begin{array}{c}\text { Modtage- } \\
\text { lighed }\end{array}$ & Udførelse & $\begin{array}{c}\text { Dimen- } \\
\text { sion 1 }\end{array}$ & $\begin{array}{c}\text { Dimen- } \\
\text { sion 2 }\end{array}$ & $\begin{array}{c}\text { Dimen- } \\
\text { sion 3 }\end{array}$ \\
\hline 6. Relation til instruktør & $\mathrm{X}$ & & $\mathrm{X}$ & & \\
\hline 7. $\quad$ Gensidig enighed om mål & $\mathrm{X}$ & & $\mathrm{X}$ & $\mathrm{X}$ & \\
\hline 8. $\quad$ Motivation til forandring & $\mathrm{X}$ & & & $\mathrm{X}$ & \\
\hline 9. Sætter prosociale mål & & $\mathrm{X}$ & & $\mathrm{X}$ & \\
\hline $\begin{array}{l}\text { 10. Forstår konsekvenserne af prokriminel } \\
\text { adfærd mod selv og andre }\end{array}$ & & $\mathrm{X}$ & & $\mathrm{X}$ & \\
\hline $\begin{array}{l}\text { 11. Viser bekymring for konsekvenserne af } \\
\text { prokriminel adfærd mod selv og andre }\end{array}$ & & $\mathrm{X}$ & & $\mathrm{X}$ & \\
\hline 12. Prosociale holdninger og værdier & & $\mathrm{X}$ & & & $\mathrm{X}$ \\
\hline
\end{tabular}




\begin{tabular}{|c|c|c|c|c|c|}
\hline $\begin{array}{l}\text { 13. Kender en række selvreguleringsfær- } \\
\text { digheder }\end{array}$ & & $\mathrm{X}$ & & & $\mathrm{X}$ \\
\hline $\begin{array}{l}\text { 14. Demonstrerer en række selvregulerings- } \\
\text { færdigheder }\end{array}$ & & $\mathrm{X}$ & & & $\mathrm{X}$ \\
\hline $\begin{array}{l}\text { 15. Anerkender relevante faktorer relateret } \\
\text { til antisocialt mønster }\end{array}$ & & $\mathrm{X}$ & & $\mathrm{X}$ & \\
\hline 16. Udvikler en plan imod tilbagefald & & $\mathrm{X}$ & & $\mathrm{X}$ & \\
\hline 17. Evne til at lære MOVE-materiale & $\mathrm{X}$ & & $\mathrm{X}$ & & \\
\hline
\end{tabular}

Note: Spørgsmålsnummereringen går fra 6-17, da det er disse tolv spørgsmål, som omhandler forhold gældende både før- og efter-deltagelsen, og derved giver mulighed for at bedømme udviklingen i GPPM som funktion af programdeltagelsen (se afsnit 2).

Som det umiddelbart fremgår, ses et næsten perfekt sammenfald mellem Modtagelighedsdimensionen i den oprindelige opdeling af spørgsmålene og dimension 1 i Berger et al. (2017). Den eneste forskel er, er spørgsmål 8 ikke indgår i dimension 1 i analysen af de danske data. Det fremgår også, at der ikke umiddelbart er et perfekt sammenfald mellem udførelses-dimensionen (Usher \& Stewart 2011) og Dimension 2 og Dimension 3 (Berger et al. 2017). I afsnit 5 om analysens resultater uddybes dette.

\subsection{Datatilgang}

Artiklens resultater er baseret på en analyse af ændringen i GPPM-scoren og afspejler, på hvilke områder deltagerne ændrer sig på de 12 målepunkter i løbet af MOVE-programmets gennemførelse. Vi har både data om GPPM før $_{\text {og }}$ GPPM $_{\text {efter }}$ samt data om deltagerens alder og LS/RNR-score inden programstart. Det giver os mulighed for at gennemføre en såkaldt Fixed effect-regressionsanalyse (Verbeek 2008). Det vil sige en statistisk analyse af ændringen/udviklingen i deltagernes GPPM afhængig af deres alder, LS/RNR- og GPPM før-score.

$\mathrm{Vi}$ har estimeret en interaktions model for ændringen i $\mathrm{GPPM}^{7}$ for hver af de to oprindelige dimensioner (Modtagelighed og Udførelse) og de tre dimensioner fundet i Berger et al. (2017). I modellerne indgår alder, LS/RNR-score (middel = 1 , høj/meget høj $=0)$ og GPPM $_{\text {før }}$ som uafhængige variable. Alder indgår som to dummyvariable, der deler respondenterne op i tre nogenlunde lige store grupper: 19-30 år ( $\mathrm{N}=12), 31-37$ år $(\mathrm{N}=12)$ og over 37 år $(\mathrm{N}=11)$. Vi inkluderer desuden interaktionsvariable mellem alder og LS/RNR-scoren. Der er balance i antallet af observationer mellem aldersgrupperne og LS/RNR-scoren. Det skal pointeres, at datamaterialet ikke er stort, da der alene er tale om et pilotstudie. Men som det vil 
fremgå af resultaterne, finder vi til trods for dette signifikante relationer i langt de

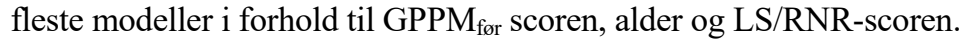

Modellerne kan ses i appendiks $\mathrm{A}$, mens de estimerede relationer, når der tages højde for interaktionerne mellem alder og LS/RNR-scoren, præsenteres i næste afsnit om analysens resultater.

\section{Analysens resultater}

De estimerede relationer mellem alder, LS/RNR og GPPM-scoren, da deltagerne startede på MOVE-programmet, er vist i Tabel 2. I de efterfølgende underafsnit præsenteres resultaterne.

\section{Tabel 2: Interaktionsmodeller for gennemsnitsdata og forskellige opdelinger af data}

\begin{tabular}{|c|c|c|c|c|c|c|}
\hline & & \multicolumn{2}{|c|}{$\begin{array}{c}\text { Oprindelige Dimensioner } \\
\text { (Usher \& Stewart 2011) }\end{array}$} & \multicolumn{3}{|c|}{$\begin{array}{l}\text { MOVE Dimensioner } \\
\text { (Berger et al. 2017) }\end{array}$} \\
\hline & & $\begin{array}{l}\text { Modtage- } \\
\text { lighed }\end{array}$ & Udførelse & Dimension 1 & $\begin{array}{c}\text { Dimension } \\
2\end{array}$ & Dimension 3 \\
\hline $\mathrm{GPPM}_{\text {før }}$ & & $\begin{array}{c}-0.616+ \\
{[0.319]}\end{array}$ & $\begin{array}{c}-0.740^{* *} \\
{[0.214]}\end{array}$ & $\begin{array}{r}-0.382 \\
{[0.326]}\end{array}$ & $\begin{array}{l}-0.768^{*} \\
{[0.286]}\end{array}$ & $\begin{array}{l}-0.824^{*} \\
{[0.328]}\end{array}$ \\
\hline \multirow[t]{2}{*}{ Alder:19-30 år } & $\begin{array}{c}\text { Middel } \\
\text { LS/RNR, } \\
\mathrm{N}=7\end{array}$ & $\begin{array}{r}0.920 * * \\
{[0.237]}\end{array}$ & $\begin{array}{r}1.014 * * * \\
{[0.159]}\end{array}$ & $\begin{array}{r}0.603 * * \\
{[0.243]}\end{array}$ & $\begin{array}{r}1.215^{* * *} \\
{[0.213]}\end{array}$ & $\begin{array}{r}0.751^{* *} \\
{[0.244]}\end{array}$ \\
\hline & $\begin{array}{c}\text { Høj/Meget } \\
\text { Høj LS/RNR, } \\
\text { N=5 }\end{array}$ & $\begin{array}{r}0.010 \\
{[0.251]}\end{array}$ & $\begin{array}{c}0.362 * \\
{[0.169]}\end{array}$ & $\begin{array}{r}-0.127 \\
{[0.257]}\end{array}$ & $\begin{array}{r}0.327 \\
{[0.225]}\end{array}$ & $\begin{array}{r}0.280 \\
{[0.258]}\end{array}$ \\
\hline \multirow[t]{2}{*}{ Alder:31-37 år } & $\begin{array}{c}\text { Middel } \\
\text { LS/RNR, } \\
\mathrm{N}=6\end{array}$ & $\begin{array}{l}0.531+ \\
{[0.260]}\end{array}$ & $\begin{array}{r}0.642 * * * \\
{[0.175]}\end{array}$ & $\begin{array}{r}0.426 \\
{[0.266]}\end{array}$ & $\begin{array}{r}0.727 * * \\
{[0.234]}\end{array}$ & $\begin{array}{l}0.598+ \\
{[0.268]}\end{array}$ \\
\hline & $\begin{array}{c}\text { Høj/Meget } \\
\text { Høj LS/RNR, } \\
\text { N=6 }\end{array}$ & $\begin{array}{c}0.531^{*} \\
{[0.234]}\end{array}$ & $\begin{array}{r}0.449^{* *} \\
{[0.157]}\end{array}$ & $\begin{array}{c}0.497^{*} \\
{[0.240]}\end{array}$ & $\begin{array}{c}0.478^{*} \\
{[0.210]}\end{array}$ & $\begin{array}{l}0.430+ \\
{[0.241]}\end{array}$ \\
\hline \multirow[t]{2}{*}{ Alder:38-52 år } & $\begin{array}{c}\text { Middel } \\
\text { LS/RNR, } \\
\mathrm{N}=6\end{array}$ & $\begin{array}{r}-0.230 \\
{[0.235]}\end{array}$ & $\begin{array}{r}0.248 \\
{[0.158]}\end{array}$ & $\begin{array}{r}-0.270 \\
{[0.241]}\end{array}$ & $\begin{array}{r}0.151 \\
{[0.211]}\end{array}$ & $\begin{array}{r}0.137 \\
{[0.242]}\end{array}$ \\
\hline & $\begin{array}{c}\text { Høj/Meget } \\
\text { Høj LS/RNR, } \\
\mathrm{N}=5\end{array}$ & $\begin{array}{c}0.640^{*} \\
{[0.251]}\end{array}$ & $\begin{array}{r}0.313+ \\
0.169\end{array}$ & $\begin{array}{c}0.660^{*} \\
{[0.257]}\end{array}$ & $\begin{array}{r}0.359 \\
{[0.225]}\end{array}$ & $\begin{array}{r}0.320 \\
{[0.258]}\end{array}$ \\
\hline$N$ & & 35 & 35 & 35 & 35 & 35 \\
\hline$R^{2}$ & & 0.452 & 0.422 & 0.352 & 0.412 & 0.258 \\
\hline Justeret $R^{2}$ & & 0.335 & 0.298 & 0.214 & 0.286 & 0.100 \\
\hline
\end{tabular}




\section{1. $G P P M_{\text {for }}$}

Som det fremgår af Tabel 2, er estimatet for GPPM-scoren, før kurset begynder, $\left(\mathrm{GPPM}_{\text {før }}\right)$ signifikant i Modtagelighed og Udførelse modellerne. Det ses, at en

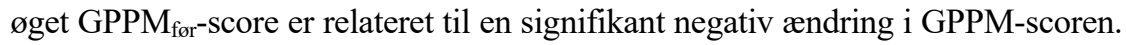
Eller sagt med andre ord, så viser modellen, at jo højere GPPM før $_{\text {-score deltager- }}$ ne har, inden MOVE-programmet starter, desto mindre gavn har de af programmet. Signifikante relationer er også estimeret i MOVE-dimensionerne 2 og 3 . Det skal pointeres, at der i MOVE-dimension 1 også er estimeret en negativ relation mellem GPPM $_{\text {før }}$-variablen og ændringen i GPPM, men den er ikke signifikant.

\subsection{Alder 19-30 år}

Går vi videre til deltagerne i alderen 19-30 år, er der på tværs af de to oprindelige dimensioner og de tre MOVE dimensioner sammenfald i forhold til, at de unge med en middel LS/RNR-score har signifikant og positivt gavn af fængselsprogrammet med ændringsværdier på mellem $0,60 \mathrm{og} 1,13$. Omvendt ser det ud med de unge med en høj eller meget høj LS/RNR-score. I løbet af MOVE-programmet er det kun i forhold til udførelsesdimensionen, at disse unge forbedrer sig signifikant, men der ikke er nogle signifikante forbedringer i modtagelighedsdimensionen eller de tre MOVE-dimensioner. Det ses også, at de 19-30-årige med en høj eller meget høj LS/RNR generelt klarer sig signifikant dårligere end de 19-30-årige med en middel LS/RNR-score. Dette peger på, at der er store forbedringspotentialer for de 19-30-årige med høj eller meget høj LS/RNR på tværs af de to oprindelige såvel som de tre MOVE-dimensioner.

\subsection{Alder 31-37 år}

For aldersgruppen 31-37 år er der stor sammenfald i resultaterne på tværs af de to oprindelige dimensioner og de tre MOVE-dimensioner blandt deltagerne med en høj eller meget høj LS/RNR-score. Deltagerne forbedrer sig signifikant med mellem 0,43 og 0,53. Førstnævnte er dog kun signifikant på et $90 \%$ niveau. Forskellene er lidt større i aldersgruppen med en middel LS/RNR-score. Der varierer ændringen i GPPM mellem 0,426 og 0,727, hvor estimater på 0,426 i dimension 1 ikke er signifikant forskelligt fra 0 . Det peger altså i retningen af, at deltagerne mellem 31-37 år med en middel LS/RNR-score ikke har signifikant gavn af fængselsprogrammet i forhold til denne dimension. Interessant viser en test, at der ikke er forskel mellem det udbytte deltagerne i aldersgruppen 31-37 år har af MOVEprogrammet på tværs af middel og høj/meget høj LS/RNR-score. Dette indikerer, at der er et ensartet udbytte af MOVE-programmet uafhængigt af LS/RNR-scoren på tværs af de to oprindelige demensioner og de tre MOVE-dimensioner. 


\subsection{Alder 38-52 år}

Deltagerne i aldersgruppen 38-52 år har forskellig gavn af MOVE-programmet afhængig af LS/RNR-scoren og på tværs af de to oprindelige og de tre MOVEdimensioner. Hvis vi starter med de to oprindelige dimensioner, så viser en test (ændring GPPR Høj/Meget $\mathrm{Høj}$ LS/RNR $=\mathrm{GPPR}_{\text {Middel LS/RNR }}$ ) at deltagerne med en høj/meget høj LS/RNR har signifikant større gavn af MOVE-programmet sammenlignet med den tilsvarende aldersgruppe med en middel LS/RNR. Det samme ses i dimension 1 i MOVE-data. Går vi videre til at sammenligne de to oprindelige og de tre MOVE-dimensioner, så peger begge de oprindelige dimensioner på, at deltagerne med en høj/meget høj LS/RNR-score har signifikant og positiv gavn af MOVE-programmet, om end kun signifikant på et 90\% niveau i udførelsesdimensionen. I forhold til MOVE-dimensionerne er dette kun gældende for Dimension 1 .

\section{Diskussion}

Vores analyse viser, at resultaterne i mindre grad end forventet afspejler de to oprindelige og teoretisk forankrede dimensioner (Modtagelighed og Udførelse), som Usher og Stewart (2011) har fremhævet i deres arbejde. Vores analyse på baggrund af vores data peger på, at der er tre - og ikke to - separate dimensioner i spil, når man tager udgangspunkt i de danske data. Spørgsmålet er da, hvad dette resultat egentlig har af betydning for fortolkningen af målingerne og i forhold til den videre anvendelse i praksis i forbindelse med feedback til de indsatte og mere generelt til kvalificering og styrkelse af indsatsen?

Vi vil i den følgende diskussion anlægge et kritisk-konstruktivt blik på brugen af GPPM med udgangspunkt i de fundne resultater. Dette indebærer, at vi som udgangspunkt anser faglig praksis som udspillet situationelt, hvor mening konstrueres i mødet mellem instruktør og deltager (se fx Eskelinen et al. 2008). Dette implicerer, at enhver meningstilskrivelse i én lokal kontekst (som fx den danske kontekst) typisk vil variere på en anden måde end den ville gøre i en anden, men tilsvarende kontekst. I forlængelse vil vi argumentere for, at resultatet af vores analyse med de tre dimensioner i høj grad kan forstås som en konsekvens af, at vi er gået fra en canadisk kontekst til en skandinavisk kontekst. Vi hævder altså ik$\mathrm{ke}$, at vores model på et overordnet og generisk niveau er bedre og mere præcis end Usher og Stewarts model. Forskellene mellem de fundne dimensioner må antages i høj grad at afspejle de forskellige kontekster, som de udspringer af.

Samtidig er der dog grund til at gå ind i diskussion af, hvorvidt de fundne forskelle også har nogle bredere og mere teoretiske implikationer. I det følgende vil vi diskutere, hvordan de tre dimensioner, som vi på baggrund af data fra MOVE- 
programmet har identificeret, kan forstås teoretisk. Særlig vil vi se nærmere på, hvordan de tre dimensioner adskiller sig fra de to i den oprindelige model, og hvad dette kan have af betydning. I forlængelse af dette vil vi argumentere for, at resultaterne peger på et potentiale i forhold til praksis. Dette potentiale ligger i, at der er nogle dimensioner, der kan udvikles for at gøre MOVE-programmet mere effektivt og målrettet.

Usher og Stewarts (2011) grundlæggende argumentation er, at man kan vurdere programmerne ud fra to meningsfuldt adskilte dimensioner, nemlig deltagernes modtagelighed (Responsivity) og udførelsen (Performance). Med modtagelighed menes de grundlæggende forudsætninger, som skal være til stede i et fængselsprogram, for at deltageren har mulighederne for at lære fra det aktuelle program. Dette gælder for eksempel at have en god relation til instruktøren, at der opnås enighed om deltagerens mål med programmet, at man som udgangspunkt er motiveret for deltagelsen og man kan kognitivt kan tilegne sig og forstå betydningen af materialet fra programmet. Udførelsen omhandler nogle centrale mål for indsatsen, som deltageren skal opnå på baggrund af fængselsprogrammet, som eksempelvis øget selvregulering samt pro-sociale holdninger og værdier.

Vi fandt i vores analyse af det danske fængselsprogram (MOVE) tre dimensioner. I det følgende vil vi benytte Usher og Stewarts model som afsæt for at diskutere og præcisere indholdet i disse tre dimensioner. Dér, hvor forskellen mellem de to modeller er mindst, er i forhold til dimension 1, hvor der ses et næsten perfekt sammenfald med modtageligheds-dimensionen. Den eneste forskel er, at spørgsmål 8 i Usher \& Stewarts model (motivation til forandring) ikke indgår i vores dimension 1 , men i stedet indgår i dimension 2 . Vores dimension 1 kan derfor med fordel også rummes under overskriften »Modtagelighed «.

Dimension 2 handler om, hvorvidt man indgår i en form for konstruktivt samarbejde omkring målene for den specifikke indsats. Dette indebærer, at deltageren kender spillereglerne og forventningerne i forhold til at indgå i programmet. Vi betoner i denne tolkning altså det aspekt, at deltagerens interesse og engagement - eller motivation om man vil - opstår og konstrueres i den konkrete situation i mødet mellem deltager og instruktør. Vores resultat peger i retning af, at 'motivation' i denne sammenhæng ikke er knyttet til individet per se (en deltagerspecifik forudsætning), men at den snarere må forstås som resultatet af den specifikke praksis, som finder sted i programmets udførelse i mødet mellem deltagerne og instruktøren.

Dimension 2 udtrykker også i hvilken udstrækning, deltagerne ser et formål og mening med deltagelsen ('er deltagelsen relevant for mig?'), og hvor realistiske målene anses for at være. Det indebærer, at der skal være en villighed til at 
sætte de nødvendige pro-sociale mål og aktivt $u d v i s e$ forståelse for, at kriminel adfærd har negative konsekvenser. Dette kan konkret indebære, at deltageren udformer en plan for, hvordan denne selv undgår at begå kriminalitet i fremtiden. Dette vil i MOVE programmet blive vurderet positivt. Dimension 2 kan derfor passende få etiketten »Forståelse og mening med deltagelse«. I MOVEmaterialet er der et tillægsblad, som angiver eksempler, som skal støtte instruktørens vurdering og angivelse af scoren, og her formuleres for eksempel, hvad den højeste score $(+2)$ til spørgsmål 16 refererer til: »Udmærket plan, der er meget detaljeret og realistisk, inkl. brug af færdigheder, personlige ressourcer og kommunale ressourcer for at adressere alle relevante risikofaktorer."

Dimension 3 (spørgsmål 12-14) kan karakteriseres som forhold, der omhandler den enkeltes tilbøjelighed og evne til at handle og regulere sin adfærd i overensstemmelse med omgivelsernes krav. Det indebærer, at man som deltager skal erkende og demonstrere, at man besidder bestemte individuelle sociale kompetencer. Dimension 3 kan derfor passende få etiketten »Social kompetence og selvkontrol«. De normative krav er altså, at man udviser pro-social adfærd: adfærd som kommer andre/samfundet til gode, fx gennem relationer karakteriseret ved empati, hjælp, støtte etc.

Opsummeret kan man sige, at dimension 3 forudsætter en mindre grad af refleksivitet og rationel omtanke end dimension 2 (Forståelse og mening med deltagelse). Dimension 1 reflekterer det relationelle aspekt mellem instruktøren og deltageren samt den kognitive forudsætning for at kunne lære af materialet fra programmet. I forhold til vores estimerede dimension 2 ser vi, at den kun på nogle punkter matcher udførelses-dimensionen i den oprindelige model. Som nævnt indgår motivationsfaktoren i denne estimerede dimension. Derudover indgår også den »gensidige enighed om mål«, hvilket umiddelbart peger i retning af, at de mål, som programmet sætter, indgår løbende som en parameter i forhold til deltagernes vurdering af programmets udbytte. I den oprindelige model var det forudsat, at det var en parameter, der spillede ind i begyndelsen af programforløbet og ikke i løbet af programmets udførelse. Endelig ses det, at der er tre spørgsmål (spørgsmål 12-14), der ikke indgår i vores egen estimerede dimension 2 (Forståelse og mening med deltagelse), men indgår i Udførelse dimensionen i den oprindelige model. Disse spørgsmål omhandler nogle centrale elementer i forhold til deltagernes sociale omgang med hinanden (pro-sociale holdninger og selvreguleringsfærdigheder). Vores analyse peger på, at disse elementer skal ses som en selvstændig gruppe af faktorer (dimension 3: Social kompetence og selvkontrol), som påvirker deltagernes udbytte, og ikke som en del af de faktorer, som Usher og Stewart (2011) har rubriceret under Udførelses-dimensionen. 
Det ses endvidere, at vores modeller understøtter vores hypotese om, at alder og LS/RNR-score har en heterogen relation til de konkrete spørgsmål, som GPPM-scoren estimeres ud fra. Alder sammenholdt med GPPM-score har en signifikant betydning i forhold til, hvad deltagerne får ud af det pågældende program. Det peger på, at man i en målrettet indsats på området med fordel både kan tage udgangspunkt i klassificeringen af spørgsmål i de tre dimensioner (vores tilpassede model) og tage udgangspunkt $\mathrm{i}$ de forskellige aldersgrupper ( $\mathrm{fx}$ yngre deltagere med middel LS/RNR-score). Det vil medføre en mere målrettet indsats og opfølgning, end hvis man baserer en indsats og opfølgning ud fra Ushers og Stewart oprindelige model med to dimensioner. Det fremgik af vores analyse af det danske fængselsprogram (MOVE), at unge deltagere med høj|meget høj LS/RNR har et markant mindre udbytte af programmet i forhold til deres relation til instruktøren, gensidig enighed om mål og evne til at lære MOVE-materialet (MOVE-dimension 1). Tilsvarende gør sig gældende for de ældre deltagere med en middel LS/RNR-score. Til gengæld, er der ingen forskel mellem de ældre deltagere, når GPPM-scoren baseres på MOVE-dimension 2 (Forståelse og mening med deltagelse) og slet ingen forskel mellem alder og LS/RNR-scoren i MOVEdimension 3 (Social kompetence og selvkontrol).

Et eksempel på, hvordan resultaterne af analysen af GPPM-data for MOVEprogrammet med de tre identificerede dimensioner kan give input til en bedre udnyttelse af potentialet i fængselsprogrammer er, at man i højere grad kunne rette en indsats mod unge med høj LS/RNR. Dette kunne ske gennem et mere målrettet arbejde med de forhold, som dækkes af dimension 2 (Forståelse og mening med deltagelse). Også dimension 1 (Modtagelighed) ville med fordel kunne styrkes yderligere.

På baggrund af analysens resultater kunne man også overveje hensigtsmæssigheden i primært at fokusere på indsatte med højest risiko, som den foretrukne målgruppe for enhver intervention i fængslet. Dette indebærer, at risikovurderingen er det styrende princip, og at lavrisiko-indsatte som udgangspunkt modtager en mindre indgribende intervention. Det indebærer en fare for, at lavrisiko-indsatte modtager utilstrækkelige indsatser, og at sandsynligheden for, at de recidiverer bliver større. Sådanne differentiale effekter af afsoning i fængsel afhængigt af risikoniveau har tidligere forskning også peget på, og vores resultater støtter dette perspektiv (Smith 2006).

\section{Konklusion}

I denne artikel har vi undersøgt latente dimensioners indvirkning på relationerne mellem alder, LS/RNR-score og ændringer i GPPM-scoren ud fra data fra et 
dansk fængselsprogram (MOVE). Ud over at give indblik i variationen i disse relationer er denne artikel den første videnskabelige produktion, der arbejder med GPPM-scoren uden for den canadiske kontekst, som den er udviklet i.

Vores model giver et andet og mere nuanceret billede af de underliggende forhold, der er afgørende for indsattes progression og udvikling i en dansk/skandinavisk kontekst, end hvis man havde taget udgangspunkt i canadiske forhold. Overordnet kan man sige, at vores analyse bekræfter udgangspunktet for den canadiske RNR model og præmisserne for GPPM scoren: Man kan også i en dansk kontekst tale om, at der er nogle typer af forudsætninger for at indgå i et fængselsprogram, som spiller sammen, og samlet set har en indflydelse på, hvad deltagerne får ud af det pågældende program. Resultaterne viser imidlertid også, at der er nogle ganske væsentlige forskelle mellem den canadiske model og den i artiklen præsenterede danske/skandinaviske model. Dette indikerer, at den canadiske model ikke er en universel og generel model, som uproblematisk kan bruges på tværs af alle nationale kontekster, men at der er behov for, at modellen tilpasses nationale kontekster for at få maksimal værdi.

Vores resultater kan ikke bruges til en generel validering af LS/RNR-scorens brugbarhed i dansk/skandinavisk kontekst - dertil er der endnu tale om et for spinkelt datagrundlag. Resultaterne giver dog anledning til, at man bør se nærmere på, om og hvordan LS/RNR-værktøjet kan tænkes proaktivt i forhold til den fremtidige programvirksomhed og andre programmer i Kriminalforsorgen (fx Andrews og Bonta 1994, 2010, Miller og Rollnick 2002).

Resultaterne peger på, at LS/RNR-scoren har en betydning for, hvilken ændring i GPPM-scoren deltagerne i MOVE-programmet oplever. Dette har en betydning for, hvilken type programmer den indsatte skal tilbydes og omfanget af programdeltagelse under afsoning, men også programmernes konkrete indhold. Der kan være et potentiale i at undersøge forskellige differentieringer mellem deltagerne og deres udbytte, sådan at man i højere grad kan tilpasse programindsatserne til de indsatte, så udbyttet af deltagelsen maksimeres og hermed bidrager til at reducere frafaldet. Et klart eksempel på dette er, at alder i vores studie har en signifikant betydning for behandlingsudbyttet (unge med høj risiko-profil får eksempelvis relativt mindre udbytte af indsatsen), og at nogle risiko-profiler har en markant betydning i forhold til behandlingsudbyttet (indsatte med lav-risiko modtager eksempelvis markant mindre indgribende indsatser).

LS/RNR-redskabet bruges aktuelt kun til at risiko-behovsvurdere. Vores analyse viser imidlertid, at man også kan bruge LS/RNR proaktivt. Hermed menes, at man på baggrund af analyser som vores kan differentiere mellem forskellige typer af deltagere og derved målrette/tilpasse programmet mere præcist til den 
enkeltes forudsætninger. En sådan mulighed har man ikke haft tidligere, men med LS/RNR og en national tilpasning af dette redskab åbnes nogle muligheder herfor, som vi har demonstreret $i$ artiklen.

\section{Noter}

1. Measuring treatment outcomes of prison efforts: A discussion of the GPPM

2. I den canadiske kriminalforsorg tager alle programmer udgangspunkt i kognitiv-adfærdsteori.

3. Spørgsmål 1-5 vurderes efter deltagelsen i programmet, mens spørgsmålene 6-17 både vurderes før og efter deltagelsen (se tabel 1).

4. LS/RNR er et risiko- og behovsvurderingsredskab. Scoren kommer fra en screening af de indsatte, som foretages ved opstart af afsoning og som fornyes hver 12. måned. Se i øvrigt afsnit 4 .

5. The Level of Service/Risk-Need Responsivity Inventory.

6. En mere systematisk analyse af frafaldet peger på, at jo ældre deltageren er og jo højere før GPPM-score deltageren har, desto større er sandsynligheden for, at deltageren gennemfører MOVE-programmet. LS/RNR-scoren har ikke nogen signifikant betydning for deltagelse, ligesom der heller ikke synes at være nogen tendens til, at frafaldet er større blandt de 6 deltagere, der startede i februar 2016 sammenlignet med de deltagere, der startede senere samme år (se Berger et al. (2017) for en mere detaljeret gennemgang).

7. Vi har kørt en test for selektionsbias i forhold til, hvem der falder fra, og hvem der gennemfører MOVE i forhold til ændringen i GPPM-scoren. Heckman-modellen (Heckman 1979, 153-161) kan ikke afvise uafhængighed mellem, hvem der gennemfører og ikke gennemfører MOVE. Det tyder på, at resultaterne fra Fixed effect-modellen ikke er biased på grund af selektion.

\section{Referencer}

Andrews, D.A., \& Bonta, J. (1994). The Psychology of criminal conduct. Cincinnati: Anderson. Andrews, D.A. (1995). The psychology of criminal conduct and effective treatment. In J.

McGuire (Ed.), What works: Reducing reoffending: Guidelines from research and practice. New York: Wiley.

Andrews, D.A. (2001). Principles of effective correctional programs. In L.L. Motiuk \& R.C. Serin (Eds.), Compendium 2000 on effective correctional programming (pp. 9-17). Ottawa,

Andrews, D.A., Bonta, J., \& Wormith, S.J. (2008). The Level of Service/Risk-Need-Responsivity $(L S / R N R)$. Toronto, Ontario, Canada: Multi-Health Systems. Ontario: Correctional Services of Canada.

Andrews, D.A., \& Bonta, J. (2010). Rehabilitating criminal justice policy and practice. Psychology, Public Policy and Law, 16(1), 39-55.

Andrews, D.A., Bonta, J., \& Wormith, J.S. (2011). The Risk-Need Responsivity model: Does the Good Lives Model contribute to effective crime prevention? Criminal Justice and Behavior, 38 (5), 735-755. 
Berger, Nichlas Permin, Ulf Hjelmar, Jacob Ladenburg, and Joan Schersat Mikkelsen. (2017). MOVE - Evaluering Af Et Motivationsprogram for Indsatte i Et Fangsel KORA, Det Nationale Institut for Kommuners og Regioners Analyse og Forskning.

Berger, Nichlas Permin og Ulf Hjelmar (2017). Risk-Need-Responsivity i danske fænglser - en status. I KRIM: 50 års kriminalpolitik. Resultater og visioner. København.

Christopher T. and Edward J. Latessa 2005 Does Correctional Program Quality Really Matter? The Impact of Adhering to the Principles of Effective Interventions. University of Cincinnati, Division of Criminal Justice.

Clausen, Susanne (2017). Alternativer til fængselsstraf - årsager til stigende anvendelse. I KRIM: 50 års kriminalpolitik. Resultater og visioner. København.

Cullen, F.T., Jonson, C.L., \& Nagin, D.S. (2011). Prisons do not reduce recidivism: The high cost of ignoring science. Prison Journal, 91(3), 48S-65S

Eskelinen, Leena; Søren Peter Olsen og Dorte Caswell (2008). Potentialer i socialt arbejde. Et konstruktivt blik på faglig praksis. København: Hans Reitzels Forlag.

Heckman, James J. (1979). »Sample Selection Bias as a Specification Error.« Econometrica 47 (1): 153-161.

Kyvsgaard, Britta (2001) Penal Sanctions and the Use of Imprisonment in Denmark. I: Penal Reform in Owercrowded Times. Red. Michael Tonry. New York. Oxford University Press.

Kiresuk, T.J., \& Sherman, R.E. (1968). Goal Attainment Scaling: A general method for evaluation comprehensive community mental health programs. Community Mental Health Journal, 4(6), 443-53.

Kiresuk, T.J., et al., Eds. (1994). Goal Attainment Scaling: Applications, Theory, and Measurement. Hillsdale, N.J., Lawrence Erlbaum Associates.

Miller, W. and S. Rollnick. (2002). Motivational interviewing: Preparing people for change. New York, NY: Guilford Press.

Nagin, Daniel S. \& Cullen, Francis T. \& Jonson, Cheryl. (2009). Imprisonment and Reoffending. Crime and Justice. 38(1), 115-200.

Smith, Paula (2006). The Effects of Incarceration on Recidivism: A Longitudinal Examination of Program Participation and Institutional Adjustment in Federally Sentenced Adult Male Offenders. PhD dissertation, University of New Brunswick, Department of Psychology.

Stewart, L. (2005). The Generic Program Performance Measure (GPPM). Ottawa, Ontario: Reintegration Programs, Correctional Service of Canada.

Usher, A. and L. Stewart (2011). Validation of the Generic Program Performance Measure (GPPM). Ottawa: Correctional Service of Canada.

Verbeek, Marno (2008). A Guide to Modern Econometrics. Chichester, England; Hoboken, NJ: Chichester, England; Hoboken, NJ: John Wiley \& Sons.

Wilson, James and Robert C. Davis (2006). Good intentions meet hard realities: An evaluation of the Project Greenlight reentry program. Criminology \& Public Policy, 5(2), 303-33.

Wilson, David B., Leanna A. Bouffard and Doris L. MacKenzie (2005). A quantitative review of structured, group-oriented, cognitive-behavioral programs for offenders. Criminal Justice and Behavior 32(2), 172-204. 
Berger, Ladenburg, Hjelmar - Måling af behandlingsudbyttet affcengselsindsatser ...

Appendiks A: Fixed effekts modeller

\begin{tabular}{|l|cc|ccc|}
\hline & \multicolumn{2}{|c|}{$\begin{array}{c}\text { Oprindelige Dimensioner } \\
\text { (Usher \& Stewart 2011) } \\
\text { Modtage- }\end{array}$} & Udførelse & \multicolumn{3}{|c|}{$\begin{array}{c}\text { MOVE Dimensioner } \\
\text { (Berger et al. 2017) }\end{array}$} \\
& $\begin{array}{l}\text { lighed } \\
\text { 1. Modtage- } \\
\text { lighed }\end{array}$ & $\begin{array}{c}\text { 2. Forståelse } \\
\text { og mening } \\
\text { med deltagelse }\end{array}$ & $\begin{array}{c}\text { 3. Social kom- } \\
\text { petence og } \\
\text { selvkontrol }\end{array}$ \\
\hline Alder:19-30 år & $-0.629^{+}$ & 0.0497 & $-0.787^{*}$ & -0.0315 & -0.0392 \\
& {$[0.355]$} & {$[0.238]$} & {$[0.363]$} & {$[0.318]$} & {$[0.365]$} \\
Alder:31-37 år & -0.109 & 0.137 & -0.163 & 0.119 & 0.110 \\
& {$[0.342]$} & {$[0.230]$} & {$[0.350]$} & {$[0.307]$} & {$[0.352]$} \\
Middel LS/RNR & $-0.870^{*}$ & -0.0643 & $-0.930^{*}$ & -0.207 & -0.182 \\
& {$[0.345]$} & {$[0.232]$} & {$[0.353]$} & {$[0.309]$} & {$[0.354]$} \\
GPPM & $-0.616^{+}$ & $-0.740^{* *}$ & -0.382 & $-0.768^{*}$ & $-0.824^{*}$ \\
& {$[0.319]$} & {$[0.214]$} & {$[0.326]$} & {$[0.286]$} & {$[0.328]$} \\
Alder:19-30 år x & $1.780^{* * *}$ & $0.717^{*}$ & $1.660^{* *}$ & $1.095^{*}$ & 0.653 \\
Middel LS/RNR & {$[0.474]$} & {$[0.319]$} & {$[0.485]$} & {$[0.426]$} & {$[0.488]$} \\
Alder:31-37 år x & $0.871^{+}$ & 0.257 & $0.859^{+}$ & 0.456 & 0.351 \\
Middel LS/RNR & {$[0.483]$} & {$[0.325]$} & {$[0.494]$} & {$[0.433]$} & {$[0.496]$} \\
Konstant & $0.640^{*}$ & $0.313^{+}$ & $0.660^{*}$ & 0.359 & 0.320 \\
& {$[0.251]$} & {$[0.169]$} & {$[0.257]$} & {$[0.225]$} & {$[0.258]$} \\
\hline$N$ & 35 & 35 & 35 & 35 & 35 \\
$R^{2}$ & 0.422 & 0.452 & 0.352 & 0.412 & 0.258 \\
Justeret $R^{2}$ & 0.298 & 0.335 & 0.214 & 0.286 & 0.100 \\
\hline
\end{tabular}

